\title{
Mitogen and muscle extract induced in vitro proliferative responses in myasthenia gravis, dermatomyositis, and polymyositis ${ }^{1}$
}

\author{
R. P. LISAK ${ }^{2}$ AND B. ZWEIMAN \\ From the Department of Neurology and Allergy and Immunology Section, \\ Department of Medicine, School of Medicine, University of Pennsylvania, \\ and the Multiple Sclerosis Research Center of the Department of Neurology and Wistar Institute, \\ Pennsylvania, U.S.A.
}

SYNOPSIS We have compared the lymphocyte in vitro proliferative response induced by muscle extract, phytohaemagglutinin, and pokeweed mitogen in peripheral blood lymphocytes of patients with myasthenia gravis, polymyositis, dermatomyositis, and normal subjects. Similar mean responses to antigen and mitogen were seen in cells of all groups of patients. The proliferative responses induced by muscle did not differ in thymic cells from myasthenics as compared with those from cardiac surgery controls. Our findings do not support the hypothesis that cell-mediated immunity to muscle or major impairment of lymphocyte responses to mitogens occurs in these diseases.

Myasthenia gravis, polymyositis, and dermatomyositis represent disorders of the neuromuscular system in which a possible autoimmune aetiology has been suggested. These disorders have been investigated using several in vitro parameters that are considered to correlate with cell-mediated hypersensitivity (Bloom, 1971). These include in vitro lymphocyte proliferative response, buffy coat migration inhibition, and direct cell-mediated lymphocytolysis of muscle cultures. Using such techniques, studies have been published suggesting that cell-mediated hypersensitivity to muscle is a concomitant and perhaps causative mechanism of both myasthenia gravis (Alpert et al., 1972; Goust et al., 1974) and polymyositis (Currie et al., 1971; Johnson et al., 1972; Dawkins and Mastaglia, 1973; Esiri et al., 1973; Goust et al., 1974; Haas and Arnason, 1974). Evidence has likewise been presented, using lymphocyte mediated cytotoxicity and inhibition of thymic cell migration, suggesting that there are cells within the myas-

\footnotetext{
1 Supported by USPHS Grant No. 1 PO1 NS11037-02, 5 KO7NS11061-03 5 TO1 A1-00319 and A1-10591-03.

2 Address for correspondence: Dr Robert P. Lisak, Department of Neurology, Hospital of the University of Pennsylvania, 3400 Spruce Street, Philadelphia, Pennsylvania 19174, U.S.A.

(Accepted 20 January 1975.)
}

thenic thymus sensitized to muscle (Armstrong et al., 1973). We sought to investigate the in vitro proliferative response to muscle extract in the peripheral blood of patients with myasthenia gravis as well as in patients with polymyositis and dermatomyositis and to compare these with the responses in blood lymphocytes of controls. The in vitro proliferative response of peripheral blood lymphocytes from such subjects were all assessed after stimulation by the non-specific mitogens, phytohaemagglutinin, and pokeweed mitogen. In addition, the proliferative responses induced by skeletal muscle were compared in thymic cells obtained from myasthenic patients and cardiac surgery patients.

\section{METHODS}

PATIENTS Patients with myasthenia gravis, defined by variable voluntary skeletal muscle weakness responsive to anticholinesterase administration (Simpson, 1969; Rowland and Layzer, 1973), were divided into two groups: one group consisted of 21 patients who had not undergone therapeutic thymectomy and the other group consisted of 12 patients who had undergone thymectomy three months to four years before study. This latter group 
included patients with and without lymphoepithelioid thymoma. Twelve patients with polymyositis or dermatomyositis had unequivocal clinical disease accompanied by elevated serum enzymes and, in most cases, diagnostically compatible findings in a muscle biopsy (Pearson, 1969; Rowland and Layzer, 1973). The normal controls consisted of 11 subjects (ages 15-59 years) with no known neurological or immunological diseases.

For the study of the in vitro proliferative response of thymic cells induced by muscle extract, tissue was obtained at therapeutic thymectomy or from small thymic biopsies obtained at open heart surgery for non-rheumatic heart disease. The glands removed at thymectomy in myasthenic patients showed thymic hyperplasia in five cases and lymphoepithelioid thymomas in three others. No patients or control subjects had been on corticosteroids or cytotoxic drugs.

LYMPHOCYTE PROLIFERATION Peripheral blood of all subjects was studied using a modification of the method of Zweiman et al. (1969). In brief, heparinized blood was sedimented with Dextran and a lymphocyte-enriched supernatant obtained. These cells were washed two times and then suspended in a final concentration of $5 \times 10^{5}$ lymphocytes $/ \mathrm{ml}$ in a culture medium containing penicillin, streptomycin, and glutamine. Agammaglobulinaemic fetal calf serum was added to a final concentration of $10 \%$. Cells were cultured in $5 \% \mathrm{CO}_{2} /$ air at $37^{\circ} \mathrm{C}$ for five days. The degree of proliferative response was assayed by the incorporation of tritiated thymidine added 18 hours before termination of the cultures. This proliferation was expressed as:

$$
\begin{gathered}
\text { Stimulation } \\
\text { Index (SI) }
\end{gathered}=\frac{\begin{array}{c}
\text { mean cpm of replicate cultures } \\
\text { with mitogen or antigen }
\end{array}}{\begin{array}{c}
\text { mean cpm of replicate cultures } \\
\text { without mitogen or antigen }
\end{array}}
$$

Cultures from all patients were incubated with phytohaemagglutinin (PHA-P; Difco Laboratories) and pokeweed mitogen in at least two concentrations (PWM; Difco Laboratories). Lymphocyte cultures from all patients were also incubated with varying doses of a saline soluble muscle extract prepared by the method of Currie et al. (1971). A stimulation index (SI) of $\geqslant 3$ in the presence of any concentration of muscle extract was considered a positive response.

Thymic cells were prepared under sterile conditions by mincing the thymic tissue and then passing them through a no. 80 steel mesh screen (Abdou et al., 1974). The cells were cultured at a concentration of $1 \times 10^{6}$ cells $/ \mathrm{ml}$ with varying concentrations of muscle for five days. The degree of stimulation (SI) was determined in a manner identical to that described for the peripheral blood lymphocytes.

\section{RESULTS}

The peripheral blood lymphocyte proliferative responses of all subjects are shown in the Table. There were no significant differences among the

TABLE

LYMPHOCYTE IN VITRO PROLIFERATIVE RESPONSES TO MITOGENS AND MUSCLE IN NEUROMUSCULAR DISEASE

\begin{tabular}{|c|c|c|c|c|c|c|c|c|}
\hline & \multicolumn{3}{|c|}{$P H A^{*}$} & \multicolumn{3}{|c|}{$P W M^{*}$} & \multirow[t]{2}{*}{ Muscle $\dagger$} & \multirow[t]{2}{*}{ Control } \\
\hline & $1: 10$ & $1: 100$ & Peak & $1: 10$ & $1: 100$ & Peak & & \\
\hline Mg§ No Tx & $\begin{array}{r}749 \\
\pm 19\end{array}$ & $\begin{array}{r}84 \\
\pm 23\end{array}$ & $\begin{array}{r}88 \\
\pm 21\end{array}$ & $\begin{array}{r}32 \\
\pm 7\end{array}$ & $\begin{array}{r}37 \\
\pm 7\end{array}$ & $\begin{array}{r}37 \\
\pm 7\end{array}$ & $\begin{array}{r}2.7 \\
\pm 1.2\end{array}$ & $\begin{array}{r}1334 \\
\pm 256\end{array}$ \\
\hline Post-Tx & $\begin{array}{r}73 \\
\pm 20\end{array}$ & $\begin{array}{r}69 \\
\pm 17\end{array}$ & $\begin{array}{r}81 \\
+19\end{array}$ & $\begin{array}{r}38 \\
\pm 11\end{array}$ & $\begin{array}{r}24 \\
\pm 6\end{array}$ & $\begin{array}{r}39 \\
\pm 10\end{array}$ & $\begin{array}{r}1.2 \\
\pm 1.0\end{array}$ & $\begin{array}{r}1043 \\
\pm 254\end{array}$ \\
\hline PM-DM & $\begin{array}{r}77 \\
\pm 24\end{array}$ & $\begin{array}{r}90 \\
\pm 27\end{array}$ & $\begin{array}{r}127 \\
\pm 28\end{array}$ & $\begin{array}{r}47 \\
\pm 4\end{array}$ & $\begin{array}{r}48 \\
\pm 6\end{array}$ & $\begin{array}{r}49 \\
\pm 9\end{array}$ & $\begin{array}{r}1.1 \\
\pm 0.1\end{array}$ & $\begin{array}{r}901 \\
\pm 309\end{array}$ \\
\hline Normal§ & $\begin{array}{r}67 \\
\pm 18\end{array}$ & $\begin{array}{r}102 \\
\pm 27\end{array}$ & $\begin{array}{r}93 \\
\pm 23\end{array}$ & $\begin{array}{r}35 \\
\pm 8\end{array}$ & $\begin{array}{r}36 \\
\pm 8\end{array}$ & $\begin{array}{r}37 \\
\pm 9\end{array}$ & $\begin{array}{r}1.1 \\
\pm 0.1\end{array}$ & $\begin{array}{r}1209 \\
\pm 287\end{array}$ \\
\hline
\end{tabular}

* PHA- phytohaemagglutinin-P; group mean responses to PHA; 1:10 and 1:100: 0.1 ml of these concentrations added to $0.9 \mathrm{ml}$ of cell suspension; peak: mean of greatest response regardless of concentration of individual subjects. PWM : pokeweed mitogen.

+ Muscle: saline muscle extract; peak response represented.

‡ Group mean counts per minute (cpm) of unstimulated (control) cultures.

§ MG No TX: Myasthenia gravis; no thymectomy; MG post-Tx: Myasthenia gravis post-thymectomy; PM-DM; polymyositis and dermatomyositis; normals: normal adult subjects.

I Stimulation index $(\mathrm{SI})=\frac{\text { mean cpm with mitogen or antigen }}{\text { mean cpm without mitogen or antigen }}$ 
groups in the mean degrees of the proliferative responses to PHA at any concentration studied. There was no difference in the response to PWM or to muscle extract. Spontaneous uptake of the isotope was similar in unstimulated cultures (cells cultured in the absence of mitogen or antigen) in lymphocytes obtained from the three groups. Muscle extract induced proliferative responses of $\geqslant 3$ were seen in lymphocytes of only two subjects. One was a patient with myasthenia gravis and thymoma; the S1 was 14 . Because of the patient's age ( 72 years) and the relatively well-controlled status of his myasthenia gravis, he did not undergo therapeutic thymectomy. The other was a woman with generalized myasthenia undergoing thymectomy and with thymic hyperplasia-thymitis at surgery; the SI was 22.

Several patients were studied pre- and postthymectomy; no consistent pattern was noted in the responses of their lymphocytes to either mitogens or muscle extract. In the muscle extractthymic cell cultures, the mean SI of cells from myasthenic patients $(2.2 \pm 0.6)$ was not statistically different from that of the control group $(1.2 \pm 0.6)$. In one subject, where muscle extract induced an SI of 22 in blood lymphocytes, the SI in thymic cells cultured with muscle was 5.1 .

\section{DISCUSSION}

In this study no evidence could be found for an obvious lymphocyte immunological defect in myasthenia, polymyositis, or dermatomyositis as manifested by deficient mitogen induced responses (Daguillard, 1972). It is conceivable that a more subtle defect in generalized immune responsiveness might be demonstrated in any of the studied disease states utilizing other mitogens and varying durations of lymphocyte culture. However, in another study in which peripheral blood lymphocytes were isolated by Ficoll-Hypaque gradient centrifugation, there was no difference in the in vitro PHA or PWM induced proliferative response after three or five days of culture (Abdou et al., 1974).

In this study, we found no consistent evidence of muscle extract stimulated in vitro proliferation of blood lymphocytes from myasthenics. It is true that a stimulation index of $\geqslant 3$ was seen in cells of two of 21 non-thymectomized myas- thenics, whereas such stimulation was not seen in the lymphocytes of any of the normal subjects. However, the mean response to muscle of cells of the myasthenic group as a whole was not significantly different from that of normal subjects. It is of note that thymus cells of one of the two myasthenics with muscle stimulated blood lymphocytes were also stimulated by the muscle extract.

A search for in vitro evidence of cell-mediated reactivity to tissue antigens has been made in several studies of myasthenics by a variety of techniques. Ambramsky et al. (1975) reported increased proliferation of lymphocytes from myasthenics cultured with acetylcholine receptors from electric eels. The antigen-induced inhibition of in vitro migration of the buffy coat has been utilized in a number of laboratories (Søborg and Bendixin, 1967) as a presumptive measure of preexistent cell-mediated immunity to tissue antigens. Using this technique, significant inhibition of migration of leucocytes from patients with myasthenia or polymyositis induced by several fractions of muscle extract has been reported (Alpert et al., 1972; Goust et al., 1974). Armstrong et al. (1973) have demonstrated a similar inhibition by muscle extract of the migration of thymic cells obtained from myasthenics at thymectomy.

In comparative studies, we found no in vitro stimulation by muscle extract of blood lymphocytes from any of the polymyositis or dermatomyositis patients. Such stimulation has been reported previously (Currie et al., 1971), but the responses in one of the reports were quite modest (mean SI-2.2). No stimulation index was described in the other study (Esiri et al., 1973). Other presumptive parameters of cellmediated immunity have been utilized in the study of polymyositis and dermatomyositis. Currie et al. (1971) found that lymphocytes of such patients exerted toxic effects on cultured fetal muscle. Johnson et al. (1972) reported toxic effects in fetal muscle cultured in the presence of lymphocytes from patients with polymyositis and autologous muscle. Dawkins and Mastaglia (1973) reported similar findings in cultures containing extracts of normal, rather than autologous, muscle. More recently, Haas and Arnason (1974) found increased creatine phosphokinase release from fetal muscle cultures in 
the presence of lymphocytes from patients with polymyositis.

In an approach using an electrophoretic macrophage migration inhibition test, it has been claimed (Caspary et al., 1971) that immune reactivity is present in lymphocytes of patients not only with polymyositis but also in patients with muscular dystrophy.

Although the methodology has varied in the reports just described, there is a suggestion of similar immunological reactivity against muscle in myasthenia and polymyositis. It would be somewhat surprising if such reactivity were pathogenetic in face of the disparate clinical features of the two disorders. It is possible that any immunological activity against muscle was a secondary event and/or an epiphenomenon.

The authors would like to thank Miss Cathy Cohen and Mrs Marilyn Ludwick for their expert technical assistance.

\section{REFERENCES}

Abdou, N. I., Lisak, R. P., Zweiman, B., Abrahamsohn, I., and Penn, A. S. (1974). The thymus in myasthenia gravis. Evidence for altered cell populations. New England Journal of Medicine, 291, 1271-1275.

Abramsky, O., Akaronov, A., Webb, C., and Fuchs S. (1975). Cellular immune response to acetylcholine receptor-rich fraction in patients with myasthenia gravis. Clinical and Experimental Immunology, 19, 11-16.

Alpert, L. I., Rule, A., Norio, M., Kott, E., Kornfeld, P., and Osserman, K. E. (1972). Studies in myasthenia gravis: cellular hypersensitivity to skeletal muscle. American Journal of Clinical Pathology, 58, 647-563.

Armstrong, R. M., Nowak, R. M., and Falk, R. E. (1973). Thymic lymphocyte function in myasthenia gravis. Neurology (Minneap.), 23, 1078-1083.

Bloom, B. R. (1971). In vitro approaches to the mechanism of cell-mediated immune reactions. Advances in Immunology, 13, 101-208.

Caspary, E. A., Currie, S., and Field, E. J. (1971). Sensitized lymphocytes in muscular dystrophy: evidence for a neural factor in pathogenesis. Journal of Neurology, Neurosurgery, and Psychiatry, 34, 353-356.

Currie, S., Saunders, M., Knowles, M., and Brown, A. E. (1971). Immunological aspects of polymyositis. Quarterly Journal of Medicine, 40, 63-84.

Daguillard, F. (1972). Immunologic significance of in vitro lymphocyte responses. Medical Clinics of North America, 56, 293-303.

Dawkins, R. L., and Mastaglia, F. L. (1973). Cell-mediated cytotoxicity to muscle in polymyositis. Effect of immunosuppression. New England Journal of Medicine, 228, 434 438.

Esiri, M. M., MacLennan, I. C. M., and Hazleman, B. L. (1973). Lymphocyte sensitivity to skeletal muscle in patients with polymyositis and other disorders. Clinical and Experimental Immunology, 14, 25-35.

Goust, J. M., Castaigne, A., and Moulias, R. (1974). Delayed hypersensitivity to muscle and thymus in myasthenia gravis and polymyositis. Clinical and Experimental Immunology, $18,39-47$.

Haas, D. C., and Arnason, G. B. W. (1974). Cell-mediated immunity in polymyositis. Creatine phosphokinase release from muscle cultures. Archives of Neurology, 31, 192-196.

Johnson, R. L., Fink, C. W., and Ziff, M. (1972). Lymphotoxin formation by lymphocytes and muscle in polymyositis. Journal of Clinical Investigation, 51, 2435-2449.

Pearson, C. M. (1969). Polymyositis and related disorders. In Disorders of Voluntary Muscle, 2nd edn, pp. 501-539. Edited by J. N. Walton. Churchill: London.

Rowland, L. P., and Layzer, R. B. (1973). Muscular dystrophies, atrophies, and related diseases. In Clinical $\vec{C}$ Neurology, 3rd edn, vol. 3, pp. 1-100. Edited by A. B, $\bigcirc$ Baker and L. H. Baker. Harper and Row: Hagerstown. Md.

Simpson, J. A. (1969). Myasthenia gravis and myastheni๕o syndromes. In Disorders of Voluntary Muscle, 2nd edn, pp. 541-578. Edited by J. N. Walton. Churchill: London.

Søborg, M., and Bendixin, G. (1967). Human lymphocyte migration as a parameter of hypersensitivity. Acta Medica Scandinavica, 181, 247-256.

Zweiman, B., Pappagianis, D., Maibach, H., and Hildreth, E. A. (1969). Coccidioidin delayed hypersensitivity: skin test and in vitro lymphocyte reactivities. Journal of Immunology, 102, 1284-1289. 